\title{
Origin and Evolution
}

of

Interplanetary Dust

A. C. Levasseur-Regourd H. Hasegawa

(editors)

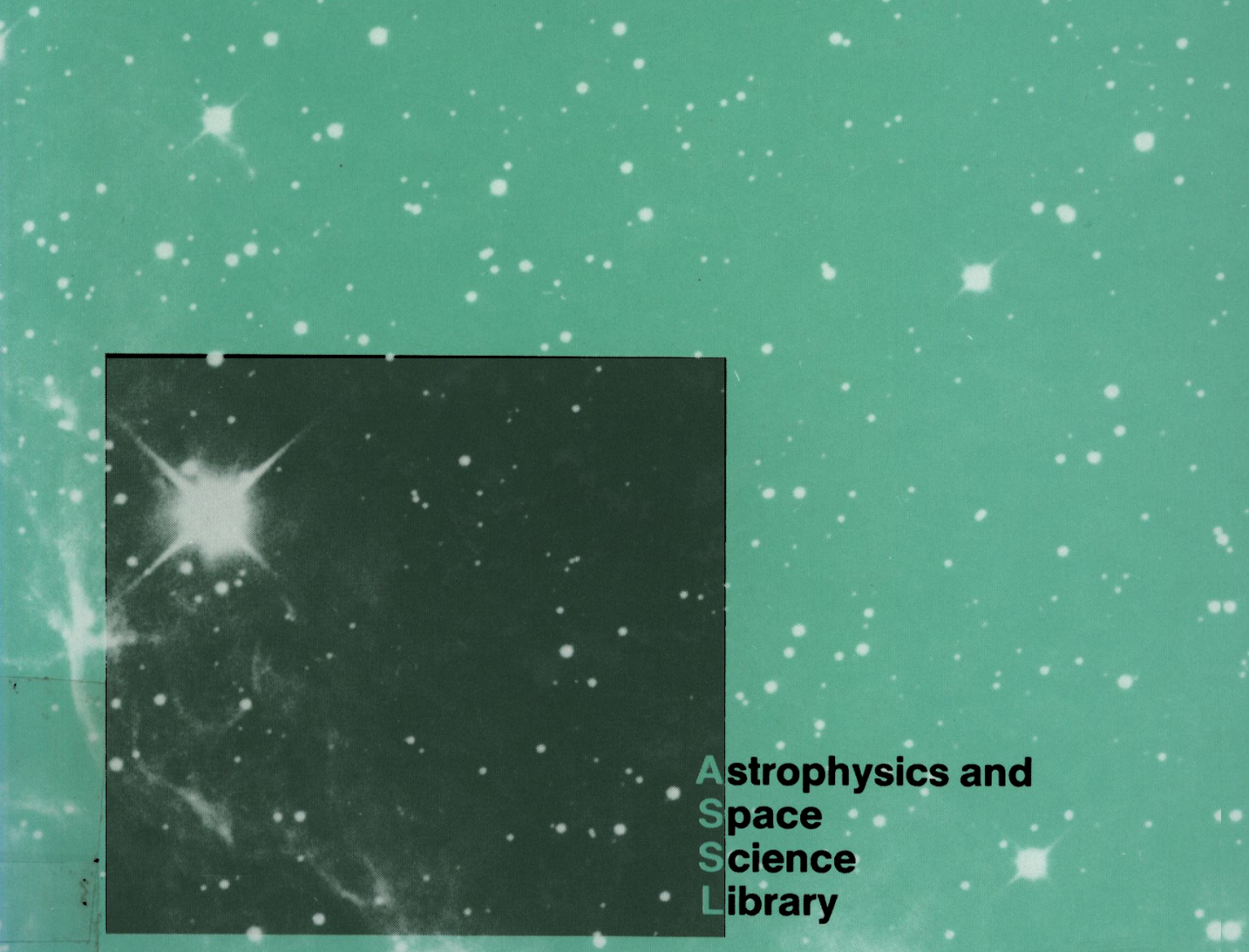

Kluwer Academic Publishers 


\section{ORIGIN AND EVOLUTION \\ $\mathrm{OF}$ \\ INTERPLANETARY \\ DUST}




\title{
ASTROPHYSICS AND SPACE SCIENCE LIBRARY
}

\author{
A SERIES OF BOOKS ON THE RECENT DEVELOPMENTS \\ OF SPACE SCIENCE AND OF GENERAL GEOPHYSICS AND ASTROPHYSICS \\ PUBLISHED IN CONNECTION WITH THE JOURNAL \\ SPACE SCIENCE REVIEWS
}

\section{Editorial Board}

R. L. F. BOYD, University College, London, England

W. B. BURTON, Sterrewacht, Leiden, The Netheriands

C. DE JAGER, University of Utrecht, The Netherlands

J. KLECZEK, Czechoslovak Academy of Sciences, Ondrejov, Czechoslavakia

Z. KOPAL, University of Manchester, England

R. LÜST, European Space Agency, Paris, France

L. I. SEDOV, Academy of Sciences of the U.S.S.R., Moscow, U.S.S.R.

Z. ŠVESTKA, Laboratory for Space Research, Utrecht, The Netherlands

\section{PROCEEDINGS}

VOLUME 173 


\section{ORIGIN AND EVOLUTION \\ $\mathrm{OF}$ \\ INTERPLANETARY \\ DUST}

PROCEEDINGS OF THE 126TH COLLOQUIUM OF THE

INTERNATIONAL ASTRONOMICAL UNION,

HELD IN KYOTO, JAPAN, AUGUST 27-30, 1990

Edited by

A. C. LEVASSEUR-REGOURD

Université Paris VI, Aeronomie CNRS, Verrières-le-Buisson, France

H. HASEGAWA

Osaka Sangyo University, Osaka, Japan

KLUWER ACADEMIC PUBLISHERS

DORDRECHT / BOSTON / LONDON 


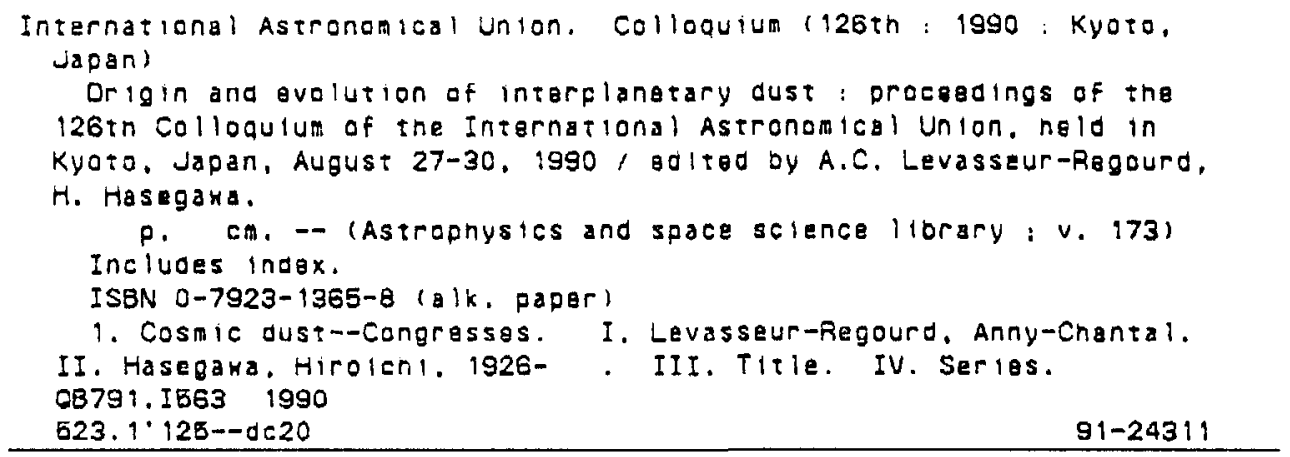

Published by Kluwer Academic Publishers,

P.O. Box 17, 3300 AA Dordrecht, The Netherlands.

Kluwer Academic Publishers incorporates the publishing programmes of

D. Reidel, Martinus Nijhoff, Dr W. Junk and MTP Press.

Sold and distributed in the U.S.A. and Canada

by Kluwer Academic Publishcrs,

101 Philip Drive, Norwell, MA 02061, U.S.A.

In all other countries, sold and distributed

by Kluwer Academic Publishers Group,

P.O. Box 322, 3300 AH Dordrecht, The Netherlands.

All Rights Reserved

(C) 1991 Kluwer Academic Publishers

No part of the material protected by this copyright notice may be reproduced or utilized in any form or by any means, electronic or mechanical, including photocopying, recording or by any information storage and retrieval system, without written permission from the copyright owner.

Printed in Japan 


\title{
TABLE OF CONTENTS
}

\author{
PREFACE \\ GROUPE PICTURE \\ LIST OF PARTICIPANTS \\ ORGANIZING COMMITTEES \\ NECROLOGY
}

\section{I - INTERPLANETARY DUST :}

\section{SPACE AND EARTH ENVIRONMENT STUDIES}

3 PARTICULATE DETECTION IN THE NEAR EARTH SPACE ENVIRONMENT ABOARD THE LONG DURATION EXPOSURE FACILITY LDEF : COSMIC OR TERRESTRIAL ? (Invited review).

J.A.M. McDonnell, K Sullivan, T.J. Stevenson and D.H. Niblett

11 STUDY OF COSMIC DUST PARTICLES ON BOARD LDEF AND MIR SPACE STATION

J.C. Mandeville

15 THE PRESENT STATUS OF THE MUNICH DUST COUNTER EXPERIMENT ON BOARD OF THE HITEN SPACECRAFT (Invited contribution)

E. Igenbergs, A. Hüdephol, K. Uesugi, T. Hayashi, H. Svedhem, H. Iglseder,

G. Koller, A. Glasmachers, E. Grün, G. Schwehm, H. Mizutani,

T. Yamamoto, A. Fugimura, N. Ishii, H. Araki, K. Yamakoshi and K. Nogami

21 IN-SITU EXPLORATION OF DUST IN THE SOLAR SYSTEM AND INITIAL RESULTS FROM THE GALILEO DUST DETECTOR (Invited review)
E. Grün, H. Fechtig, M.S. Hanner, J. Kissel, B.A. Lindblad, D. Linkert,
G. Morfill and H.A. Zook.

29 THE NASA SOLAR PROBE MISSION : IN SITU DETERMINATION OF INTERPLANETARY OUT-OF-THE ECLIPTIC AND NEAR-SOLAR DUST ENVIRONMENTS

B. T. Tsurutani and J. E. Randolph

33 COLLECTION OF COSMIC DUST FROM THE STRATOSPHERE

W. Gucun, O. Ziyuan, X. Yiwen and W. Xiguang

37 DYNAMIC MODELLING TRANSFORMATIONS FOR THE LOW EARTH ORBIT SATELLITE PARTICULATE ENVIRONMENT

J.A.M. Mc Donnell, K. Sullivan, S.F. Green, T.J. Stevenson and

D.H. Niblett

41 FACE-DEPENDENT IMPACT PROBABILITIES UPON LDEF FOR HELIOCENTRIC PARTICLE ORBITS
D. Steel 
45 THE MUNICH DUST COUNTER : A COSMIC DUST EXPERIMENT ON BOARD OF THE MUSES-A MISSION OF JAPAN

E. Igenbergs, A. Hüdepohl, K. Uesugi, T. Hayashi, H. Svedhem, H. Iglseder,

G. Koller, A. Glasmachers, E. Grün, G. Schwehm, H. Mizutani,

T. Yamamoto, A. Fujimura, N. Ishii, H. Araki, K. Yamakoshi and K. Nogami

49 COLLECTION OF STRATOSPHERIC MICROPARTICLES ABOVE THE SULFATE LAYER USING BALLOON-BORNE COLLECTORS

J.R. Stephens, Y. Nakada, T. Onaka and F.J.M. Rietmeijer

53 A COSMIC MATTER ACCRETION EVENT AROUND 660000 YEARS BEFORE PRESENT FOUND IN TWO DATED, CENTRAL PACIFIC CORES

K. Yamakoshi, K. Nogami and R. Omori

57 PRELIMINARY STUDY ON NEOGENE MICROTEKTITES IN THE CORE COLLECTED FROM NORTH PACIFIC

P. Hanchang, L. Zhenkun, Z. Shijie, M. Xueying and C. Zhifang

\section{II - INTERPLANETARY DUST :}

\section{PHYSICAL AND CHEMICAL ANALYSIS}

63 PHYSICAL AND MINERALOGICAL PROPERTIES OF ANHYDROUS INTERPLANETARY DUST PARTICLES IN THE ANALYTICAL ELECTRON MICROSCOPE (Invited review)

J.P. Bradley

71 AQUEOUS ALTERATION IN HYDRATED INTERPLANETARY DUST PARTICLES (Invited review)

K. Tomeoka

79 THE EFFECT OF TOTAL PRESSURE ON VAPORIZATION OF ALKALIS FROM PARTIALLY MOLTEN CHONDRITIC MATERIEL

T. Shimaoka and N. Nakamura

83 CONDENTATION EXPERIMENTS OF MG-SILICATE MINERALS

A. Tsuchiyama

87 ULTRAVIOLET-INDUCED AMORPHIZATION OF CUBIC ICE AND ITS IMPLICATION FOR THE EVOLUTION OF ICE GRAINS

A. Kouchi and T. Kuroda

91 SIMULATION IN LABORATORY OF SOLID GRAINS PRESENT IN SPACE

L. Colangeli, E. Bussoletti and V. Mennella

95 THE INFRARED SPECTRA OF SYNTHESIZED AMORPHOUS SILICATES WITH COMPOSITIONS OF OLIVINE AND PYROXENE

C. Koike and A. Tsuchiyama 
99 OPTICAL CONSTANTS OF KEROGEN FROM 0.15 TO $40 \mu \mathrm{m}$ : COMPARISON WITH METEORITIC ORGANICS
B.N. Khare, W.R. Thompson, C. Sagan, E.T. Arakawa, C. Meisse and

I. Gilmour

102 OPTICAL CONSTANTS OF BASALTIC GLASS FROM 0.0173 TO $50 \mu \mathrm{m}$

E.T. Arakawa, D.W. Young, J.M. Zhang, P.C. Eklund, B.N. Khare, W.R. Thompson and C. Sagan

105 NOBLE METAL ENRICHMENTS IN COSMIC SPHERULES

K. Nogami, K. Misawa, R. Omori, M. Jianguo and K. Yamakoshi

109 STUDIES ON ISOTOPIC RATIOS OF OSMIUM AND IRIDIUM IN COSMIC SPHERULES USING INSTRUMENTAL NEUTRON ACTIVATION ANALYSIS

K. Yamakoshi and K. Nogami

113 STRUCTURES OF AMORPHOUS SILICATE DUSTS SIMULATED BY MOLECULAR DYNAMICS METHOD

A. Tsuchiyama and K. Kawamura

117 ASTROPHYSICAL INTERESTING COMPOUND GRAINS PRODUCED BY A GAS EVAPORATION METHOD

C. Kaito and Y. Saito

121 MEASUREMENT OF FAR-INFRARED ABSORPTION FOR AMORPHOUS SILICATES BETWEEN 27 AND $400 \mu \mathrm{m}$

C. Koike and H. Shibai

125 LABORATORY SPECTRA OF AMORPHOUS AND CRYSTALLINE OLIVINE : AN APPLICATION TO COMET HALLEY IR SPECTRUM

A. Blanco, V. Orofino, E. Bussoletti, S. Fonti, L. Colangeli and J.R. Stephens

III - INTERPLANETARY DUST : ZODIACAL LIGHT AND OPTICAL STUDIES

131 THE ZODIACAL CLOUD COMPLEX (Invited review)

A.C. Levasseur-Regourd, J.B. Renard and R. Dumont

139 SPATIAL DISTRIBUTION AND ORBITAL PROPERTIES OF ZODIACAL DUST (Invited review)

B. Kneissel and I. Mann

147 ON THE GEGENSCHEIN AND THE SYMMETRY PLANE

S.S. Hong and S.M. Kwon

151 ULTRAVIOLET OBSERVATIONS OF THE ZODIACAL LIGHT AND THE ORIGIN OF INTERPLANETARY DUST GRAINS

C.F. Lillie 
155 LIGHT SCATTERING BY DUST PARTICLES IN THE OUTER SOLAR SYSTEM

J.W. Hovenier and P.B. Bosma

159 LIGHT SCATTERING BY SOLAR SYSTEM DUST : THE OPPOSITION EFFECT AND THE REVERSAL OF POLARIZATION

K. Muinonen and K. Lumme

163 THE OPTICAL PROPERTIES OF INTERPLANETARY DUST (Invited review)

P.L. Lamy and J.M. Perrin

171 THE INFRARED ZODIACAL LIGHT (Invited review)

M.S. Hanner

179 TEMPORAL AND SPATIAL VARIATIONS OF THE ATMOSPHERIC DIFFUSE LIGHT

S.M. Kwon, S.S. Hong, J.L. Weinberg

183 FINE RESOLUTION BRIGHTNESS DISTRIBUTION OF THE VISIBLE ZODIACAL LIGHT

S.M. Kwon, S.S. Hong, J.L. Weinberg and N.Y. Misconi

187 INTERPLANETARY DUST CLOSE TO THE SUN

I. Mann

191 FUTURE OBSERVATIONS OF THE F-CORONA WITH THE LASCO CORONAGRAPH SPACE EXPERIMENT

P.L. Lamy, A. Llebaria, A. Maucherat, S. Koutchmy and F. Giovane

195 SYNTHETIC MAPS OF THE BRIGHTNESS AND POLARIZATION OF THE F-CORONA

Y. Fang, P.L. Lamy and A. Llebaria

199 OPTICAL PROPERTIES OF INTERPLANETARY DUST IN THE TANGENTIAL PLANE

J.B. Renard, A.C. Levasseur-Regourd and R. Dumont

203 SCATTERING CALCULATIONS ON THE BASIS OF FREDHOLM INTEGRAL EQUATION METHOD

M. Matsumura and M. Seki

207 THE SCATTERING MATRIX OF RANDOMLY ORIENTED INFINITE CYLINDERS

P. Stammes

211 ASTEROIDAL DUST AND THE ZODIACAL EMISSION

W. T. Reach 
IV - COMETARY DUST :

OBSERVATIONS AND EVOLUTION

217 SPECTROSCOPIC EVIDENCE OF ORGANIC MOLECULES RELEASED BY THE DUST OF HALLEY'S INNER COMA

J. Clairemidi, P. Rousselot and G. Moreels

221 MODELING DUST FRAGMENTATION IN COMETS

I. Konno and W.F. Huebner

225 THE CONTRIBUTION OF LONG PERIOD COMETS TO THE INTERPLANETARY DUST CLOUD

M. Fulle and G. Cremonese

229 LONG DUST TRAILS OF SHORT PERIOD COMETS (Invited contribution)

H.U. Keller and K. Richter

235 COMETS AS A SOURCE OF INTERPLANETARY AND INTERSTELLAR GRAINS

(Invited contribution)

F. Hoyle and N.C. Wickramasinghe

241 CHEMICAL COMPOSITION OF AN EMANATION FROM COMETS : IDENTIFICATION OF THE 3 MICRON COMET FEATURE

A. Sakata, S. Wada and A.T. Tokunaga

245 SPECTROPOLARIMETRY OF COMET HALLEY

N. Visvanathan, Z. Meglick and D.T. Wickramasinghe

249 SCATTERING PROPERTIES OF COMETARY DUST BASED ON POLARIMETRIC DATA

S. Mukai, T. Mukai and S.Kikuchi

253 SYNCHRONIC BAND AND ITS IMPLICATION IN THE COMETARY DUST

J.I. Watanabe and K. Nishioka

257 ICE PARTICLE EMISSION FROM COMETARY ANALOGUE SAMPLES

H. Kohl and E. Grün

261 THE DUST IN THE COMA OF COMET HALLEY

J.I. Hage and J.M Greenberg

265 POLYOXYMETHYLENE IN COMETARY DUST : LABORATORY TESTS

D.C. Boice, D.W. Naegeli and W.F. Huebner

269 ON THE ANTI-TAIL OF COMET BRADFIELD 1987XXIX

H. Akisawa, T. Oka and K. Sugawara

273 FORMATION MECHANISMS OF THE SPLIT TAIL OF COMET BRADFIELD 1987XXIX

K. Sugawara and J.I. Watanabe 
277 SPATIAL DISTRIBUTION AND COLOR OF DUST IN HALLEY'S INNER COMA

J. Clairemidi, E. Brandon, P. Rousselot and G. Moreels

281 PENETRATION OF HYPERVELOCITY PROJECTILES INTO LOW DENSITY MATERIALS

A. Fujiwara, T. Kadono, A. Nakamura, T. Ishibashi and N. Fujii

285 POLARIMETRIC PROPERTIES OF HALLEY'S DUST

A.K. Sen, M.R. Deshpande and U.C. Joshi

\section{V - METEOROIDS AND METEOR STREAMS}

291 THE ORBITAL DISTRIBUTION AND ORIGIN OF METEOROIDS (Invited review)

D. Steel

299 A STUDY OF METEOR ORBITS OBTAINED IN JAPAN

B.A. Lindblad

303 THE MICROMETEOROID IN THE UPPER ATMOSPHERE

F. Kamijo

307 AN ESTIMATION OF METEOROID FLUX AT OUTER MARTIAN SPACE FOR STEADY METEOR STREAMS

K. Nagasawa

311 THE IAU METEOR DATA CENTER IN LUND

B.A. Lindblad

$315 \eta$ LYRID METEOR STREAM ASSOCIATED WITH COMET IRAS-ARAKI-ALCOCK, 1983VII

K. Ohtsuka

319 THE ANNUAL VARIATION OF RADIO METEOR ECHOES OBSERVED FROM 1981 TO 1985

K. Suzuki

323 LIFETIME OF METEOR STREAMS ASSOCIATED WITH COMET HALLEY

M. Hajdukova and A. Hajduk

327 THE TAURID COMPLEX : GIANT COMET ORIGIN ?

D.I. Steel, D.J. Asher and S.V.M. Clube

331 MASS DISTRIBUTION AND BULK DENSITY DISTRIBUTION OF INTERPLANETARY DUST
A. Hajduk

335 THE INTERNATIONAL METEOR ORGANIZATION

M. Gyssens, A. Knöfel J. Rendtel and P. Roggemans 
VI - CIRCUMPLANETARY DUST : COLLISIONAL AND ELECTROSTATIC PROCESSES

341 PHYSICAL PROCESSES ON CIRCUMPLANETARY DUST (Invited review)

J. A. Burns

349 DUST IN PLANETARY RING SYSTEMS (Invited review)

M. R. Showalter

357 READING SATURN'S RING SPOKES

L.R. Doyle and E. Grün

361 CATASTROPHIC DISRUPTION OF SOLID BODIES BY COLLISION EXPERIMENTAL APPROACH (Invited review)

A. Fujiwara

367 METHODS, DIFFICULTIES AND FIRST RESULTS IN LABORATORY SIMULATION OF COSMIC DUST ELECTRIC CHARGING

J. Sveska and E. Grün

371 ELECTROSTATIC FRAGMENTATION OF IRREGULARLY SHAPED PARTICLES

T. Mukai

375 PLASMA EMISSION FROM HIGH VELOCITY IMPACTS OF MICROPARTICLES

ONTO WATER ICE

T. Timmermann and E. Grün

379 VELOCITY DISTRIBUTION OF FRAGMENTS IN COLLISIONAL BREAKUP

A. Nakamura and A. Fujiwara

383 JETS OF FRAGMENTS FROM CATASTROPHIC BREAK-UP AND THEIR ASTROPHYSICAL IMPLICATIONS

G. Martelli, P. Rothwell, P.N. Smith, I. Giblin, J. Martinsson, E. Ducrocq,

M. Wettstein, M. Di Martino and P. Farinella

VII - ORIGIN OF INTERPLANETARY DUST :

FROM COMETS AND ASTEROIDS, BACK TO INTERSTELLAR

DUST

389 COMETARY AND ASTEROIDAL SOURCES OF INTERPLANETARY DUST

(Invited review)

M.V. Sykes

397 CONSTRAINTS ON THE PARENT BODIES OF COLLECTED INTERPLANETARY DUST PARTICLES (Invited review)

S.A. Sandford 
405 CHARACTERISTICS OF INTERSTELLAR AND CIRCUMSTELLAR DUST (Invited review)
A.G.G.M. Tielens

413 CHEMICAL COMPOSITION OF DUST EXPECTED FROM CONDENSATION MODELS (Invited review)

T. Yamamoto

421 DISTRIBUTION OF DUST IN THE DISK AROUND BETA PICTORIS

T. Nakano

425 OFF-DISK IMPLANTATION OF EARLY SOLAR WIND INTO A PLANETESIMAL-DUST CLOUD

S. Sasaki

429 COMPARISON OF 3 MICRON FEATURES OF TRAPPED $\mathrm{H}_{2} \mathrm{O}$ AND $\mathrm{H}_{2} \mathrm{O}$ FROST IN $\mathrm{SiO}$ CONDENSATE WITH OBSERVED DUST FEATURES

S. Wada, A. Sakata and A.T. Tokunaga

433 THE SOURCE COMPOSITION OF GALACTIC COSMIC RAYS AS POSSIBLY ORIGINATED FROM THE DUST IN THE CIRCUMSTELLAR AND INTERSTELLAR SPACE

K. Sakurai

437 LABORATORY STUDIES OF GRAIN MANTLES IN INTERSTELLAR SPACE C.X. Mendoza-Gomez and J.M. Greenberg

\section{COLLOQUIUM SUMMARY}

443 THE INTERPLANETARY MEDIUM IS THRIVING (Invited review)

J.M. Greenberg

\section{AUTHOR INDEX}

